\title{
Нефинансовое богатство российских домохозяйств: собственность и налоги ${ }^{1}$
}

\author{
Т.Ю. БОГОМОЛОВА*, Т.Ю. ЧЕРКАШИНА**
}

\begin{abstract}
*Татьяна Юрьевна Богомолова - кандидат социологических наук, заведующий, отдел социальных проблем, Институт экономики и организации промышленного производства СО РАН; декан, экономический факультет, Новосибирский национальный исследовательский государственный университет. Адрес: 630090, Новосибирск, проспект Академика Лаврентьева, д. 17. E-mail: bogtan@rambler.ru

**Татьяна Юрьевна Черкашина - кандидат социологических наук, ведущий научный сотрудник, Институт экономики и организации промышленного производства СО РАН; заведующий, кафедра общей социологии, экономический факультет, Новосибирский национальный исследовательский государственный университет. Адрес: 630090, Новосибирск, проспект Академика Лаврентьева, д. 17. E-mail: touch@nsu.ru
\end{abstract}

Цитирование: Богомолова Т.Ю., Черкашина Т.Ю. (2021) Нефинансовое богатство российских домохозяйств: собственность и налоги // Мир России. Т. 30. № 3. С. 51-77. DOI: $10.17323 / 1811-038 X-2021-30-3-51-77$

Обладание собственностью, через которую определяют нефинансовое богатство населения, сопряжено с финансовыми обязательствами: приобретение собственности с привлечением заемных средств влечет необходимость погашения таких долгов, а налогообложение имущества физических лиц-необходимость уплаты налогов, ежегодно или ситуативно, например, при вступлении в наследование. В статье описаны (1) тенденции и результаты в накоплении собственности (нефинансового богатства) российскими домохозяйствами с серединь 1990-х годов до настоящего времени и (2) усилия российского государства по формированию более прозрачных прав и обязательств населения, связанных с собственностью (создание системы кадастрового учета, налогообложение имущества по его кадастровой стоимости, «дачная» и «гаражная амнистии» и т. д.) и стимулирование приобретения собственности через различные государственнье программы. Информационную базу представленного в статье исследования составили тексты государственных законов, распорядительных документов, ведомственная статистика, аналитические материалы, а также данные Российско-

1 Статья опубликована в рамках проекта НИУ ВШЭ по поддержке публикаций авторов российских образовательных и научных организаций «Университетское партнерство». 
го мониторинга экономического положения и здоровья населения НИУ «Высшая школа экономики» за 1994-2018 годы и Комплексного наблюдения условий жизни населения, проводимого Росстатом в 2011, 2014, 2016, 2018 годах. С серединь 1990-х годов владение активами преимущественно потребительского (основное жилье, автомобили, дачи) и инвестиционно-страхового (дополнительное к основному жилье) назначения увеличивалось, а обладание активами преимущественно производственного назначения (в данном исследовании - земля) снижалось. Данные о динамике собственности российских домохозяйств в иелом свидетельствуют, что активность государства по выведению объектов собственности в официальное поле и увеличение налогообложения не снижают желание россиян обладать собственностью.

Ключевые слова: богатство домохозяйства, нефинансовое богатство, собственность, социология прав собственности, налогообложение, государство

\section{Введение}

Для понимания того, как формируется благосостояние населения, важно проследить механизмы, работающие на то или противодействующие тому, чтобы домохозяйства обретали, накапливали, эффективно использовали экономические активы, т. е. укреплялись в статусе собственника. Именно через собственность принято определять понятие «богатство»: «богатство состоит из элементов, которые имеют определенную экономическую ценность и являются объектом права собственности» [OECD 2013, p. 123]. Это предполагает, что если мы владеем чем-то с ненулевой стоимостью, то в той или иной степени богаты, а богатство населения страны рассматривается как непрерывная переменная от минимальных значений, например в случае собственника автомобиля «Жигули» первой модели, по-прежнему находящегося на ходу, до максимальных - представленных имуществом семей бизнесменов из российского списка «Форбс».

Хотя формирование богатства домохозяйств - преимущественно рыночный процесс, тем не менее ни он сам, ни его условия ни в одной стране мира не остаются без внимания государства. Государство воздействует на формирование богатства домохозяйств созданием благоприятных институциональных условий, например, через стимулы и льготы для бизнесов, производящих объекты собственности или кредитующих их приобретение, вводя адресные программы поддержки повышения благосостояния определенных социальных групп, осуществляя налогообложение собственности в том или ином режиме.

Заинтересованность в том, чтобы население богатело как совокупный собственник, есть у всех основных участников процесса: и домохозяйств, и государства, и бизнеса. Домохозяйства стремятся приумножить свои экономические активы, поскольку это дает им возможность удовлетворять насущные и перспективные материальные потребности, создает подушку безопасности на случай индивидуальных или глобальных экономических шоков, позволяет выступать более надежным заемщиком за счет расширения залоговой базы, повышает социальный престиж и т. д. Бизнес здесь выигрывает за счет обеспечения устойчивого спроса как на объекты собственности, так и связанные с ними сервисные услуги за счет 
развития рыночной инфраструктуры кредитования, страхования, правового сопровождения растущей собственности домохозяйств.

И у государства есть свой интерес. Безусловно, наличие экономических активов у населения во многом облегчает задачу государства по противодействию национальным или глобальным экономическим шокам, но в мирное время для государства важно, чтобы у населения росли количество и качество не просто активов, а активов, видимых в институциональном пространстве, - денежные средства не наличными в «кубышке», а в виде банковских вкладов, акций, облигаций; не самозахватный садовый участок, а оформленный по всем правилам, чтобы получать налоги с собственности граждан в бюджет: чем больше активов в собственности домохозяйств, тем выше налоговые сборы. Через налогообложение собственности граждан государство реализует как минимум три цели: пополнение государственной казны, стимулирование эффективного использования собственности и регулирование экономического неравенства в обществе. При этом реализация налогообложения - весьма затратное дело. Рентабельность ведения тех или иных налогов во многом обусловлена масштабом распространения в собственности населения тех или иных объектов потенциального налогообложения и их качеством (ценностью).

В предыдущих своих публикациях, посвященных нефинансовому богатству, мы показали динамику процесса обретения российскими домохозяйствами объектов собственности в институциональном контексте новейшей истории [Богомолова, Черкашина 2018], дали описание основных характеристик имущественной стратификации в стране в завершении второй декады XXI в. [Богомолова, Черкашина 2020]. В данной статье акцент будет сделан на увязку между собой масштабов собственности и налоговых обязательств домохозяйств.

\section{Методология}

Богатство принято разделять на финансовое и нефинансовое в зависимости от характера активов, находящихся в собственности. Финансовое богатство составляют транзакционные счета, депозитные сертификаты, сберегательные облигации, акции, средства в трастовых фондах, пенсионные счета, полисы страхования жизни и прочие финансовые активы. Нефинансовое богатство - это основное жилье, другая жилая недвижимость, транспортные средства, нежилая недвижимость, включая землю, капитал, вложенный в бизнес, прочие нефинансовые активы (материальные объекты, включающие значительные по стоимости произведения искусства, ювелирные изделия, драгоценные металлы, антиквариат, оснащение для хобби и предметы коллекционирования). Владельцами активов могут выступать как домохозяйства, так и индивиды. В зарубежных социально-экономических исследованиях для количественной оценки богатства используют показатель «чистое богатство» (или «чистая стоимость богатства»), который определяется как рыночная стоимость нефинансовых активов плюс финансовые активы за вычетом долгов [Wolff 1990; Jianakopolos, Menchik 1997; Keister, Moller 2000; Paiella 2007; Nau, Tumin 2012 и др.].

В фокусе нашего исследования находится нефинансовое богатство российских домохозяйств. «Нефинансовое богатство домохозяйства - это находящиеся 
в собственности членов домохозяйства материальные (нефинансовые) активы. Основанием считать объекты собственности активами (а не ресурсами) выступает возможность использования их для конвертации в финансовые активы (обратить в деньги, продав), получения дополнительного дохода (сдать в аренду жилую недвижимость, использовать личный автомобиль как такси, грузовой автомобиль для предоставления платных услуг по перевозке грузов) или использования как залога для получения кредитов, так сказать, для рефинансирования» [Богомолова, Черкашина 2020, с. 14]. Нефинансовое богатство выступает достаточно информативным индикатором богатства в целом: так, в исследованиях богатства населения в качестве неизменного мирового тренда отмечается тот факт, что реальные (нефинансовые активы) составляют от 70 до 90\% (в стоимостном выражении) общего богатства домохозяйств [OECD 2015, p. 264; OECD 2018, p. 34].

Данное исследование имеет целью дать ответы на вопросы: как государство содействовало становлению населения собственником в России? что в итоге накопили российские домохозяйства в виде собственности (богатства)? как государство выстраивало систему его налогообложения в последние десятилетия?

\section{Таблица 1. Элементы нефинансового богатства домохозяйств, представленные в РМЭЗ НИУ ВШЭ и КОУЖ Росстата}

\begin{tabular}{|c|c|c|}
\hline $\begin{array}{l}\text { Элементы } \\
\text { нефинансового } \\
\text { богатства }\end{array}$ & РМЭЗ НИУ ВШЭ & КОУЖ \\
\hline \multirow{3}{*}{$\begin{array}{l}\text { Жилая } \\
\text { недвижимость }\end{array}$} & \multicolumn{2}{|c|}{ Находящееся в собственности членов домохозяйства основное жилье } \\
\hline & $\begin{array}{c}\text { Дополнительные } \\
\text { к основному жилью } \\
\text { квартира(-ы), комната(-ы) } \\
\text { в коммунальной квартире }\end{array}$ & $\begin{array}{c}\text { Дополнительные к основному дом или часть дома, } \\
\text { квартира, комната(-ы) в коммунальной квартире, } \\
\text { пригодные для проживания круглый год }\end{array}$ \\
\hline & $\begin{array}{c}\text { Дополнительные } \\
\text { к основному жилью дом, } \\
\text { часть дома, садовый домик }\end{array}$ & $\begin{array}{c}\text { Дополнительные к основному жилью дом или часть } \\
\text { дома, квартира, комната(-ы) в коммунальной квартире, } \\
\text { пригодные для проживания сезонно }\end{array}$ \\
\hline $\begin{array}{l}\text { Нежилая } \\
\text { недвижимость }\end{array}$ & & $\begin{array}{c}\text { Стационарный гараж или место / бокс в крытой } \\
\text { многоместной стоянке }\end{array}$ \\
\hline Земля & \multicolumn{2}{|c|}{ Земельные участки в собственности и/или распоряжении } \\
\hline $\begin{array}{l}\text { Транспортные } \\
\text { средства }\end{array}$ & $\begin{array}{c}\text { Автомобили } \\
\text { (легковой, грузовой) }\end{array}$ & $\begin{array}{c}\text { Автомобили (легковой, грузовой, автобус, микроавтобус) } \\
\text { и прочий моторный транспорт (мотоцикл, снегоход, } \\
\text { трактор и пр.) }\end{array}$ \\
\hline
\end{tabular}

Чтобы описать российский институциональный и экономический контекст становления населения собственником и выстраивания государством системы его налогообложения в последние три десятилетия, мы использовали источники информации о принятых и рассматриваемых государством законах и распорядительных документах, задействовали ведомственную статистику, релевантные тематике исследования материалы аналитических агентств. Динамика накопления российскими домохозяйствами собственности показана на материалах двух обследований: Российского мониторинга экономического положения и здоровья на- 
селения НИУ «Высшая школа экономики» (РМЭЗ НИУ ВШЭ) за 1994-2018 гг. и Комплексного наблюдения условий жизни населения (КОУЖ), проводимого Росстатом в 2011, 2014, 2016, 2018 гг. В каждом из этих обследований представлена информация о наличии в домохозяйстве нефинансовых активов, но есть отличия по составу набора активов (хотя в основном они пересекаются) (таблица 1).

В представленной статье мы используем не весь содержательный потенциал обеих баз данных, а лишь фиксируем наличие тех или иных объектов собственности у домохозяйств, оставив за скобками площадь объектов жилой недвижимости, возраст транспортных средств, размер земельных участков и т. П. Это можно считать ограничением выполненного анализа, но величина налогообложения зависит от множества факторов, а не только от характеристик объектов налогообложения.

\section{Обзор литературы}

Общим местом в публикациях, посвященных богатству домохозяйств, неравенству по богатству, является упоминание об относительной редкости баз данных, содержащих сведения о богатстве населения, сложности получения качественных данных о богатстве, проблеме с доступом к информации о нем. Отсутствие критической массы качественной и достоверной информации о богатстве населения ставит под вопрос оценки неравенства по богатству, а обращение к такой социально острой теме - весьма ответственное дело, и поэтому как объектом исследования «неравенством по богатству в значительной степени пренебрегали, вплоть до недавнего времени» [OECD 2015, p. 34]. Ключевые слова в цитате - «вплоть до недавнего времени», поскольку ко второму десятилетию XXI в. у обществоведов появились основания считать богатство домохозяйств вполне познаваемым феноменом. Это относится не только к США - стране-лидеру как по аккумуляции богатства, так и по наличию доступных для исследователей информационных источников о нем, но и к расширяющемуся кругу стран, выстраивающих систему сбора релевантной информации о богатстве населения, и даже к миру в целом. Подтверждением этому служат работы, содержащие обобщения о богатстве и экономическом неравенстве населения и 1) по группам стран - доклад «В одной лодке: почему от меньшего неравенства выигрывают все» (In It Together: Why Less Inequality Benefits All) Департамента социальной политики Организации экономического сотрудничества (ОЭСР) [OECD 2015], и 2) по планете в целом - ежегодные с 2010 г. Доклады Швейцарского банка о мировом богатстве (Credit Suisse Global Wealth Report) ${ }^{2}$.

В последние годы новые возможности для обществоведов в изучении богатства как распределенного у населения феномена (wealth) и как ресурса, сконцентрированного у узкой, закрытой, а потому упускаемой в массовых обследованиях группы (riches), появляются также в связи с тем, что правительства открывают доступ к административным данным - налоговым декларациям резидентов [Bricker et al. 2016]. Габриэль Цукман считает, что для оценки неравенства по богатству «идеальным источником были бы высококачественные налоговые декларации

2 Why Wealth Matters. The Global Wealth Report // The Credit Suisse // https://www.credit-suisse.com/about-us/en/ reports-research/global-wealth-report.html, дата обращения 29.04.2021. 
богатства для всего населения, с обширной и правдивой отчетностью финансовых учреждений, внутренних и иностранных», но при этом он констатирует, что «ни одна страна в мире не имеет такого идеального источника данных сегодня». Также он отмечает позитивный опыт Норвегии и Дании: «Данные Норвегии имеют наивысшее качество, поскольку обширная информация о большинстве активов собирается для всех норвежцев (независимо от того, облагается тот или иной элемент богатства налогом или нет). Хотя Дания прекратила облагать налогом чистое богатство в 1997 г., она также по-прежнему собирает подробные административные данные о богатстве» [Zucman 2016, p. 39].

Выше было приведено сущностное определение богатства населения через собственность. Изучение собственности охватывает пять важнейших аспектов: объекты собственности (что может принадлежать), субъекты собственности (кто может владеть), использование собственности (что можно с ней делать), обеспечение соблюдения прав (как соблюдаются правила собственности) и передача собственности (как собственность перемещается между разными владельцами). По мнению социологов из Северо-Западного университета (Иллинойс, США) Брюса Керратерса и Лауры Айриович, рассмотрение этих аспектов может составить предмет новой отрасли социологии - социологии прав собственности. Б. Керратерс и Л. Айриович вслед за Р. Сведбергом утверждают, что современная социология в значительно меньшей степени (чем могла бы и должна) уделяет внимание проблематике собственности, уступая эту тему правоведам и экономистам.

«Собственность включает в себя социально признанные экономические права. Собственность - это то, над чем получают такие права, а владельцы - это те, кто обладает этими правами» [Carruthers, Ariovich 2004, p. 23]. Между тем Б. Керратерс и Л. Айриович остерегают от следования очевидности, что собственность касается только отношений между людьми и вещами. Ссылаясь на Н. Флигстина ${ }^{3}$ и П. Шиптона ${ }^{4}$, они подчеркивают важность учета социальных и политических аспектов собственности. И вслед за Дж. Румером ${ }^{5}$ делают акцент на то, что «право контролировать, управлять и эксплуатировать вещи влечет за собой власть влиять на людей, управлять ими и эксплуатировать их» [Carruthers, Ariovich 2004, p. 23]. «Владельцы производительных активов могут препятствовать их использованию не-собственниками и тем самым формировать жизненные шансы не-владельцев. Кроме того, что отделяет собственность от простого владения, так это тот факт, что другие признают права собственности либо напрямую, либо через формальную правовую систему. Частная собственность только кажется диадической, а в действительности она всегда подразумевает триадные отношения» [Carruthers, Ariovich 2004, p. 24]. Делая отсылку к М. Веберу, Э. Дюркгейму, К. Марксу и Ф. Энгельсу, они пишут: «Пренебрежение к собственности со стороны социологии вызывает сожаление, поскольку основатели социологии знали, что права собственности имеют большое социологическое значение» [Carruthers, Ariovich 2004, p. 24].

\footnotetext{
3 Fligstein N. (2001) The Architecture of Markets: An Economic Sociology of Twenty-first-century Capitalist Societie, Princeton: Princeton University Press.

4 Shipton P. (1994) Land and Culture in Tropical Africa: Soils, Symbols, and the Metaphysics of the Mundane // Annual Review of Anthropology, vol. 23, pp. 347-377.

5 Roemer J.E. (1989) What Is Exploitation? Reply to Jeffrey Reiman // Philosophy and Public Affairs, vol. 18, no 1, pp. $90-97$.
} 
Между тем в последние годы социологи, придерживаясь взгляда на собственность как на продукт социальных отношений, активно включились в дискуссию о правах собственности. Обзорная статья М.М. Сакаевой про права собственности и правила использования собственности в фокусе социологических теорий может рассматриваться как отражение текущего состояния в становлении социологии прав собственности [Сакаева 2016].

Собственность может также включать в себя обязанность платить налоги, и налогообложение объектов собственности, следовательно, представляет собой один из способов регулирования аккумулирования, использования и передачи собственности. Актуальность изучения собственности, по мнению Б. Керратерса и Л. Айриович, вытекает из ее последствий, к важнейшим из которых они относят социально-экономическое неравенство («правила собственности регулируют доступ и контроль над ценными вещами и, следовательно, поддерживают социальное неравенство» [Carruthers, Ariovich 2004, р. 31]) и экономические показатели («права собственности имеют значение для эксплуатации ресурсов, инвестиций, роста, эффективности фирмы, кредитования и инноваций» [Carruthers, Ariovich 2004, p. 33]).

Практика и многочисленные научные исследования подтверждают эту точку зрения: «Есть веские аргументы в пользу решения проблемы неравенства в богатстве с помощью налоговой системы. Неравенство в богатстве намного больше, чем неравенство доходов, и есть свидетельства того, что неравенство в богатстве увеличилось в последние десятилетия. Кроме того, накопление богатства работает самоподдерживающимся образом и, вероятно, будет расти в отсутствие налогообложения. Люди с высоким доходом могут больше откладывать, а это означает, что они могут больше инвестировать и, в итоге, накопить больше богатства. Более того, доходность инвестиций обычно увеличивается с увеличением богатства в основном потому, что богатые налогоплательщики имеют больше возможностей для инвестирования в более рискованные активы и, как правило, имеют более высокий уровень финансовой грамотности, опыта и доступа к советам профессиональных инвесторов» [OECD 2018, p. 96].

Налог на собственность определяется как регулярные и единовременные налоги на использование, владение или передачу собственности. Перечень налогов, взимаемых с собственности, достаточно широк: регулярный налог на недвижимое имущество, текущий налог на чистое богатство, единовременные налоги на собственность; налоги на наследство, наследование и дарение; налоги на финансовые операции и операции с капиталом. Доля поступлений от налогов на собственность в совокупных налоговых поступлениях и набор инструментов налогообложения собственности по странам довольно сильно различаются. В некоторых государствах взимаются несколько видов налогов на собственность, в то время как в других обходятся одним-двумя. Для понимания российских реалий представляется полезным проанализировать характеристики налогообложения, распространенность тех или иных видов налогов на собственность и их сочетаний в странах Организации экономического сотрудничества и развития. Опыт стран - членов ОЭСР по имущественному налогообложению можно рассматривать пусть и не как репрезентативный, но точно референтный в мировом контексте, т. к. организация объединяет страны, достигшие заметных успехов в социально-экономическом развитии и/или двигающихся в этом направлении в русле совершенствования 
институциональных механизмов. Обратимся к материалам двух отчетов Комитета фискальных отношений ОЭСР: «Статистика налоговых поступлений 2020» (Revenue Statistics 2020) и «Роль и структура налогов на чистое богатство в ОЭСР» (The Role and Design of Net Wealth Taxes in the OECD), опубликованных соответственно в 2021 и 2018 гг.

Общее представление о средней структуре налоговых поступлений в странах ОЭСР могут дать данные за 2018 г.: поступления от налога на доходы индивидов, прибыль корпораций, прирост капитала составили 34,3\%, от взносов на социальное обеспечение (Social security contributions (SSC)) - 25,7\%, от налога на зарплату $-1,2 \%$, от налога на собственность $-5,6 \%$, от налога на добавленную стоимость продуктов и услуг (Value Added Tax (VAT)) - 32,7\%, от прочих налогов - 0,5\% [OECD 2021, p. 60]. Эта структура практически неизменна с 2000 г. [OECD 2021, pp. 63-69]. Поступления от налогов на собственность имеют в средней структуре налоговых поступлений стран ОЭСР относительно небольшой, хотя и стабильный на протяжении трех последних десятилетий вес: 5,6\% - в 1990 г., 5,5\% - в 2000 г., 5,5\% в 2010 г., 5,6\% - в 2018 г. [OECD 2021, p. 68], однако между странами по этому показателю имеется существенная дифференциация. Выделяется группа стран, где доля поступлений от налога на собственность в общих налоговых поступлениях выше среднего показателя в два и более раза: Великобритания (12,5\%), США $(12,5 \%)$, Корея $(11,6 \%)$, Канада $(11,6 \%)$; и есть государства, где этот показатель фиксируется на уровне $1 \%$ : Эстония $(0,7 \%)$, Литва $(1 \%)$, Словацкая Республика $(1,2 \%)$, Чешская Республика (1,3\%) [OECD 2021, p. 60]. Состав этих двух крайних групп наводит на мысль о значимости продолжительности и непрерывности истории частной собственности в стране для выстраивания эффективной системы налогообложения имущества населения.

Поступления от налогов на собственность могут направляться на нужды всех уровней власти, но наиболее значимы они для уровня муниципального (локального) управления, составляя здесь модальную статью налоговых поступлений (таблица 2).

Есть страны, где местные бюджеты практически целиком зависят от налогов на собственность: Австралия (100\%), Великобритания (100\%), Канада (97,3\%), Израиль (95,1\%), Греция (93,6\%), Ирландия (90,1\%), - и страны, где местные бюджеты наполняются прежде всего налогами на индивидуальные доходы и прибыль предприятий (90-98\%), а не налогами на собственность: Швеция (2,4\%), Люксембург (6,6\%), Финляндия (8,1\%), Дания (11\%).

Как правило, практикуется взимание нескольких видов налогов на собственность граждан. Что касается распространенности тех или иных видов налогов на собственность и их сочетаний ${ }^{6}$, то среди 35 стран в 2017 г., являющихся членами ОЭСР, взимались: регулярный налог на недвижимость - в 35 странах, налог на финансовые операции и операции с капиталом - в 33, налог на наследство, наследование или дарение богатства - в 26, единовременный налог на собственность - в 10, регулярный налог на стоимость чистого богатства населения в 6 странах; присутствуют в практике налогообложения собственности одновременно пять рассматриваемых налогов в 2 странах (Испании, Канаде), четыре

6 Для анализа использовался материал, представленный в таблице «1.1 Налоги на собственность, имевшие место в странах ОЭСР в 2017 г.» в отчете «Роль и структура налогов на чистое богатство в ОЭСР» [OECD 2018, p. 24]. 
налога - в 10 странах (Австрии, Бельгии, Великобритании, Дании, Люксембурге, Италии, Исландии, Словении, Швейцарии, Франции), три налога - в 16 странах (Германии, Израиле, Норвегии, Нидерландах, США, Японии, Чили, Финляндии, Греции, Венгрии, Ирландии, Корее, Латвии, Польше, Португалии, Турции), два налога - в 5 странах (Австралии, Мексике, Новой Зеландии, Швеции, Чешской Республике), один налог - в 2 странах (Словацкой Республике, Эстонии). Наиболее распространенное сочетание видов налогов - регулярный налог на недвижимость, налог на наследство, наследование и дарение, налог на финансовые операции и операции с капиталом; подобное сочетание присутствует в 13 из 35 стран ОЭСР (Финляндии, Германии, Греции, Венгрии, Ирландии, Японии, Корее, Латвии, Нидерландах, Польше, Португалии, Турции, США). В следующем по распространенности сочетания к предыдущему перечню налогов добавляется единовременный налог на собственность в 7 странах (Австрии, Бельгии, Великобритании, Дании, Исландии, Италии, Словении) [OECD 2018, p. 24].

Таблица 2. Доля поступлений от налогов разного вида в совокупных средних налоговых поступлениях в бюджеты соответствующего уровня управления, \%, страны ОЭСР, 2018 г.

\begin{tabular}{|l|c|c|c|c|}
\hline \multirow{2}{*}{ Вид налога } & \multicolumn{3}{|c|}{ Уровень управления } & \multirow{2}{*}{$\begin{array}{c}\text { Страны } \\
\text { ОЭСР**** }\end{array}$} \\
\cline { 2 - 5 } & Государственный* & Территориальный $* * *$ & $\begin{array}{c}\text { Муниципальный } \\
\text { (локальный)*** }\end{array}$ & 34,3 \\
\hline $\begin{array}{l}\text { Налог на индивидуаль- } \\
\text { ные доходы и прибыль } \\
\text { предприятий }\end{array}$ & 38,5 & 39,2 & 0,4 & 25,7 \\
\hline $\begin{array}{l}\text { Взносы на } \\
\text { соцобеспечение }\end{array}$ & 3,8 & 3,2 & 0,3 & 1,2 \\
\hline $\begin{array}{l}\text { Налог на заработную } \\
\text { плату }\end{array}$ & 1,4 & 13,1 & $\mathbf{4 4 , 2}$ & $\mathbf{5 , 6}$ \\
\hline Налог на собственность & $\mathbf{3 , 4}$ & $\mathbf{1 6 , 3}$ & 19,4 & 32,7 \\
\hline $\begin{array}{l}\text { Налог на добавленную } \\
\text { стоимость }\end{array}$ & 52,7 & 27,1 & 2,0 & 0,5 \\
\hline Прочие налоги & 0,2 & 1,1 & $\mathbf{1 0 0 , 0}$ & $\mathbf{1 0 0 , 0}$ \\
\hline Всего & $\mathbf{1 0 0 , 0}$ & $\mathbf{1 0 0 , 0}$ & & \\
\hline
\end{tabular}

Примечание: таблица составлена авторами на основе материалов:

* [OECD 2021, p. 72];

** [OECD 2021, p. 73];

*** [OECD 2021, p. 74];

$* * * *$ [OECD 2021, p. 60]

Собираемый во всех странах ОЭСР налог на недвижимое имущество имеет ряд очевидных преимуществ перед другими налогами на собственность, чем, собственно, и объясняется его распространенность: налоговая база и, следова-

\footnotetext{
7 При федеративном устройстве государства субъекты федерации обозначаются как штаты, земли, кантоны, провинции и пр. Среди стран - членов ОЭСР в 2018 г. федеративное устройство имели Австралия, Австрия, Бельгия, Канада, Германия, Мексика, Швейцария, США.
} 
тельно, потенциал поступления достаточно велики, поскольку жилье является основной формой богатства домашних хозяйств во всех странах ОЭСР. Кроме того, неподвижность налоговой базы ограничивает потенциальную поведенческую реакцию на налог, а ее «заметность» сокращает возможности уклонения от уплаты налогов [OECD 2018, p. 21]. Стоимость жилой недвижимости отчасти определяется качеством инфраструктуры местности, где она расположена. Таким образом, налог, который тесно связан с предоставлением местных общественных благ, в некоторой степени можно рассматривать как плату за услуги органов власти локального сообщества, а в случае высокого качества инфраструктуры и управления ею - в качестве «налога на выгоды». Считается, что налог на недвижимость имеет наименьшее искажающее влияние на поведение налогоплательщиков, т. е. желание избавиться от актива из-за данного налога или увеличения его ставки возникает очень редко ${ }^{8}$ и является «наименее вредным налогом для долгосрочного экономического роста» по сравнению с другими налогами на собственность [OECD 2018, p. 21].

Налоги на финансовые операции и операции с капиталом также действуют почти во всех странах ОЭСР и обычно составляют значительную часть доходов от налога на имущество (в 2015 г. на них приходилось в среднем немногим менее четверти общих доходов от налога на богатство) [OECD 2018, p. 23]. В большинстве стран ОЭСР также облагают налогом передачу богатства. Общей тенденцией для этих налогов является отход от налогов на наследство, взимаемых с умершего дарителя, к налогам на наследство и дарение, которые взимаются с бенефициаров. Поступления от этого вида налогов, как правило, низкие и отражают тот факт, что базы налогов на наследство или наследование и дарение часто сужаются за счет многочисленных освобождений и вычетов, а возможности уклонения широко доступны [OECD 2018, p. 23].

Реже всего задействуется такой инструмент, как регулярные налоги на активы, составляющие чистое богатство индивидов. В отличие от налогов на недвижимое имущество эти налоги охватывают широкий спектр как недвижимого, так и движимого имущества, и вообще все виды активов - нефинансовые и финансовые за вычетом долгов - что делает их администрирование очень дорогим. Кроме того, налог на чистое богатство взимается без учета того, получает или нет налогоплательщик выгоду от своих активов, что позволяет его считать менее справедливым, например, по сравнению с налогом на доход от операций с капиталом. Однако в последнее время тенденции в неравенстве доходов и богатства в сочетании с необходимостью сбалансировать государственные бюджеты после серии кризисов первых двух декад XXI в. привели к повышению интереса государств к налогам на чистое богатство [OECD 2018].

Каждое государство вводит или отменяет определенные виды налогов на собственность, расширяет или сужает перечень объектов налогообложения, формирует свой набор и ставки налогов, учитывая массу факторов: особенности богатства граждан в плане структуры активов (соотношение финансовых и нефинансовых), а также уровня богатства и характера его распределения, развитость рынка недвижимости, масштабов закредитованности собственников, стоимости

\footnotetext{
8 Однако экономический кризис 2007-2009 гг. смог стать таким триггером: в США, как многие помнят, дома продавались за 1 доллар.
} 
администрирования налогообложения, финансовой грамотности собственников, склонности населения к уклонению или избеганию налогов и прочее. Помимо этого, во внимание принимаются значимые цели и задачи, стоящие перед обществом в конкретный период времени. Наше исследование обращено к опыту российского государства по созданию системы налогообложения собственности в новейшей истории как одному из значимых контекстов, на фоне которого формировалось нефинансовое богатство населения нашей страны.

\section{Стимулы и форматы прироста нефинансового богатства российских домохозяйств}

Российское государство, сформировав в первой половине 1990-х гг. институциональные условия для массового обретения российскими домохозяйствами статуса собственников, продолжило работу по созданию новых стимулов и форматов для прироста нефинансового богатства населения параллельно с расширением мер фискальной политики в отношении собственности и собственников. В тридцатилетней государственной политике содействия приросту нефинансовых активов у российских домохозяйств можно выделить три условно хронологических (с наплывающими друг на друга временными границами) периода. Они различаются характером ключевого механизма, генерирующего новых собственников и приумножающего (или переформатирующего) портфель активов уже состоявшихся собственников. Следует отметить, что каждый последующий задействуемый государством механизм не отменял предыдущий, но государственная активность смещалась в новую плоскость, расширяя пространство возможностей для населения. Первый период охватывает 1990-е гг, его определяет приватизация общественного жилого фонда и земель сельскохозяйственного назначения.

К концу 1990-х гг. приватизация национального богатства как основной механизм массового превращения населения в обладателей нефинансового богатства себя исчерпала. Восстановление экономики России после финансового кризиса 1998 г. во многом благодаря росту цен на углеводороды стало реальностью к середине 2000-х гг: увеличились реальные доходы населения; государство запустило программы, направленные на рост жилищного строительства и производства автомобилей, дало старт развитию потребительского и ипотечного кредитования. Обозначим начало 2000-х гг. как второй период государственной политики, когда приобретение собственности с привлечением заемных средств стало основным механизмом накопления населением нефинансового богатства.

На наш взгляд, есть основания считать конец 2000-х - начало 2010-х гг. стартом третьего периода в политике государства по содействию приросту собственности у населения, когда был подключен механизм «программного» сотрудничества с населением: в это время новые возможности по обретению собственности открывались у тех, кто откликнулся на стимулы и участвовал в реализации государственных программ. Актуализировала активное обращение власти к практике государственных программ необходимость ликвидировать негативные последствия мирового экономического кризиса 2008-2009 гг., осуществляя поддержку пострадавших секторов экономики, уязвимых социально-демографических групп; 
подобное наблюдалось и в пандемический экономический кризис 2020-2021 гг. Оба упомянутых кризиса, особенно второй с его жестким локдауном, подтвердили не только значимость в случае экономических потрясений наличия у домохозяйств собственности как подушки безопасности и ресурса, повышающего степень свободы (просторное жилье в городе, дополнительное жилье за городом, автомобиль), но и зыбкость имущественного положения тех, кто имел в кризисное время кредитное обременение.

Мы уже давали подробное описание первых двух периодов в [Богомолова, Черкашина 2018]. В данной статье представим основные вехи третьего периода, когда решение проблем демографии (и не только) сопровождается не прямой помощью государства, а обеспечением доступа к льготным кредитам на приобретение объектов собственности. С конца нулевых годов стал отчетливо виден курс государства на тесную увязку демографической и семейной политики с отношениями собственности на нефинансовые активы.

В 2007 г. стартовала программа поддержки семей с детьми, предполагающая выдачу государственных сертификатов на материнский (семейный) капитал за рождение (усыновление) второго или следующего ребенка (с 2020 г. - за рождение первого ребенка). Эта программа допускает несколько вариантов использования материнского капитала, в т. ч. для улучшения жилищных условий семьи. По факту именно этот способ и стал самым востребованным: например, в 2014 г. такой вариант распоряжения материнским капиталом был указан в 90,5\% поданных за год заявлениях, в 2017 г. - в 86,1\%, в 2018 г. - 77,1\% [Годовой отчет 2017; Годовой отчет 2018]. При этом российские семьи в три раза чаще прибегают к покупке новой жилплощади, чем к ее строительству, и почти в два раза реже идут на прямую покупку жилья, чем используют для этого кредитные или заемные средства, которые впоследствии погашают средствами материнского капитала [Годовой отчет 2017].

Начавшаяся в 2019 г. государственная программа «Социально-экономическое развитие Дальневосточного федерального округа» включает подпрограмму «Дальневосточная ипотека», предусматривающую субсидирование процентной ставки до уровня $2 \%$ годовых по ипотечным жилищным кредитам на приобретение жилья молодыми семьями на Дальнем Востоке или на строительство дома на земельном участке, предоставленном по программе «Дальневосточный гектар» [Постановление Правительства № 1609 2019].

В качестве дополнительных финансовых инструментов стимулирования рождаемости Федеральный закон от 03.07.2019 № 157-Ф3 предусматривает возможность получить государственную поддержку для полного или частичного погашения задолженности по ипотечному кредиту (займу) (в размере не более 450 тыс. руб.) тем заемщикам, у которых с 1 января 2019 г. по 31 декабря 2022 г. родились третьи или последующие дети [Федеральный закон № 157-Ф3 2019].

Приверженность выбранным инструментам государство продемонстрировало и в пакете мер поддержки населения в условиях угрозы распространения новой коронавирусной инфекции, введя программу льготной ипотеки с апреля до ноября 2020 г., а затем продлив ее до 1 июля 2021 г.: ставка не выше 6,5\% сохранялась на весь период ипотечного кредитования при покупке строящегося или уже готового жилья в новостройках [Постановление Правительства № 566 2020].

Одно из возобновлений программы льготного автокредитования (2018 г.) сделало ее более адресной, и в настоящее время для получения кредитных льгот 
необходимо выполнить одно из двух условий: по программе «Первый автомобиль» автокредит на льготных условиях могут взять те заемщики, которые покупают первую в жизни машину, у заемщиков по программе «Семейный автомобиль» должно быть двое или более несовершеннолетних детей [О продлении программы льготного автокредитования 2018].

Таким образом, в последнее десятилетие государство не просто поддерживало условия для пополнения портфеля активов граждан, но и ввело в действие инструменты, в которых государственная поддержка собственника «обменивалась» на его участие в решении общенациональных проблем: государство берет на себя обязательства снижать кредитную нагрузку на бюджеты семей, вызванную приобретением собственности, в случае если семьи будут жить в регионах с высоким миграционным оттоком населения, делать вклад в естественный прирост населения, поддерживать потребительский и жилищный рынок в условиях коронакризиса и т. п.

\section{Нефинансовые активы российских домохозяйств: тенденции в обладании}

Итогом институциональных и экономических процессов, частичное описание которых было дано выше, стала следующая динамика во владении населением различными нефинансовыми активами:

- доля жилищного фонда, находящегося в собственности граждан, выросла с 26,4\% в 1990 г. до 89\% в конце 2018 г., а доля муниципального и государственного фонда сократилась с 66,9 до 7,5\% [Российский статистический ежегодник 2019, с. 176];

- на 1 января 2018 г. в собственности граждан и их объединений находились 112930,9 тыс. га земли (6,6\% от земельного фонда страны), на начало 2006 г. - 1242 млн га (7,3\%); земельные участки сельскохозяйственного назначения и находящиеся в собственности граждан (108514,0 тыс. га) на 77,5\% (84123,5 тыс. га) состояли из земельных долей, в т. ч. невостребованных (15918,9 тыс. га) [Государственный (национальный) доклад о состоянии и использовании земель 2018];

- количество легковых автомобилей в собственности граждан составило 45377 тыс. в 2018 г. по сравнению с 13688,5 тыс. в 1995 г. [Транспорт в России 2020; Транспорт и связь в России 2018]; относительная обеспеченность выросла с 93,3 собственных автомобилей на 1000 чел. населения в 1995 г. до 309, 1 в 2018 г. [Регионы России 2019, с. 256].

Динамика в обеспеченности населения основными имущественными активами отчетливо прослеживается по информации статистических сборников. Но для более глубокого понимания процесса формирования благосостояния населения нужно обратиться к микроданным - материалам репрезентативных на национальном уровне обследований населения. Здесь можно почерпнуть сведения по более широкому, чем в государственной статистике, спектру объектов собственности граждан, не говоря уже об уникальной возможности оценивать сочетание и концентрацию объектов собственности в домохозяйствах. 


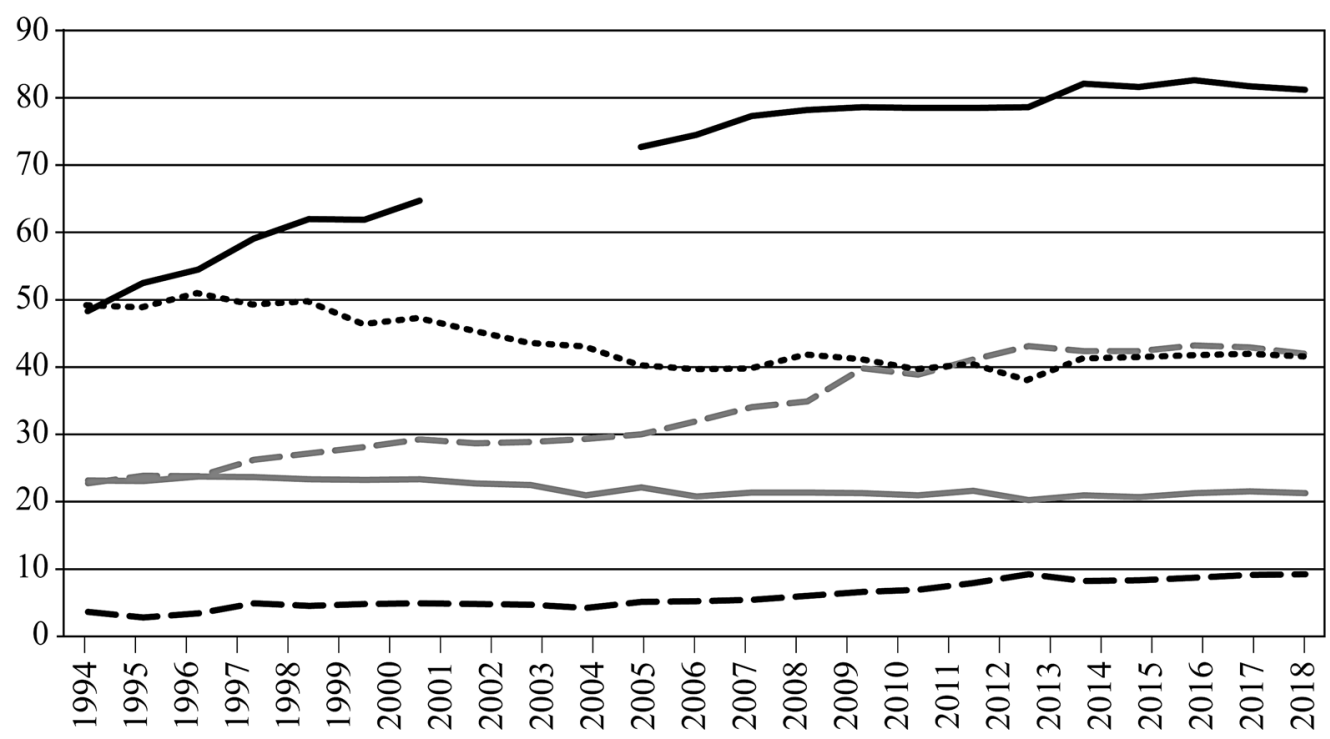

проживают в частном или приватизированном жилье,

принадлежащем кому-либо из членов домохозяйства

— имеют дачу или другой дом, часть дома, садовый домик

- - имеют другую квартиру или часть квартиры

- - имеют автомобиль (легковой или грузовой) или трактор

...... имеют землю в собственности

Рисунок 1. Численность российских домохозяйств, обладающих отдельными составляющими нефинансового богатства, РМЭЗ НИУ ВШЭ, \%

Источник: расчеты авторов по данным РМЭЗ НИУ ВШЭ.

Согласно РМЭЗ НИУ ВШЭ, в 1994-2018 гг. увеличивалось количество домохозяйств, обладающих не только основным занимаемым жильем, но и дополнительным - другой(-ми) квартирой(-ами) или комнатой(-ами) (рисунок 1). За это время доля домохозяйств, проживающих в собственном жилье, выросла с 49 до 82\%, а имеющих как минимум еще одну квартиру или комнату - с 4 до 10\%. Еще один жилищный актив - дом на садовом участке - был, по данным РМЭЗ, самым стабильным по масштабу распространенности: доля владельцев дач и других домов среди домохозяйств колебалась в 1994-2018 гг. в диапазоне 20-23\%. К концу наблюдаемого периода двукратно выросла доля домохозяйств, обладающих как минимум одним автомобилем - с 22 до 44\%. Следует отметить, что земельные участки - это единственный вид собственности, в отношении которого наблюдалась понижающая тенденция: с 1994 по 2000 г. доля собственников земли среди домохозяйств почти не менялась - 48-50\%, а с 2002 г. начала сокращаться и стабилизировалась к концу 2010-х на уровне 42-43\%.

Данные Комплексного наблюдения условий жизни населения Росстата охватывают лишь малую часть (2011-2018 гг.) хронологии РМЭЗ. Несмотря на 
некоторое расхождение величин конкретных показателей, вызванных особенностями построения выборок в этих обследованиях, КОУЖ подтверждает выявленные на материалах РМЭЗ ключевые тенденции в динамике обладания российскими домохозяйствами нефинансовыми активами, а также демонстрирует на 2018 г. тот же рейтинг нефинансовых активов российских домохозяйств по доле владельцев: на первом месте - основное жилье, далее по убыванию доли собственников - автомобиль, земля, жилье, пригодное для сезонного проживания (дача/садовый дом), дополнительное к основному пригодное для всесезонного проживания жилье (таблицьа 3).

Таблица 3. Численность российских домохозяйств, обладающих отдельными составляющими нефинансового богатства, 2011-2018 гг., КОУЖ, \%

\begin{tabular}{|l|c|c|c|c|}
\hline Элементы нефинансового богатства & $\mathbf{2 0 1 1}$ & $\mathbf{2 0 1 4}$ & $\mathbf{2 0 1 6}$ & $\mathbf{2 0 1 8}$ \\
\hline Занимаемое жилье, принадлежащее членам домохозяйства & 87,0 & 87,0 & 87,8 & 89,1 \\
\hline Дополнительное жилье, пригодное для круглогодичного проживания & 9,2 & 8,3 & 9,3 & 10,0 \\
\hline Дополнительное жилье, пригодное только для сезонного проживания & 9,0 & 8,5 & 10,0 & 10,1 \\
\hline Земельные участки в распоряжении и владении & 48,3 & 45,2 & 45,9 & 44,1 \\
\hline Автотранспортные средства & 38,4 & 41,4 & 47,2 & 47,9 \\
\hline Собственный гараж или место в крытом парковочном комплексе & 15,6 & 13,6 & 14,6 & 12,8 \\
\hline
\end{tabular}

В КОУЖ есть информация о владении домохозяйствами таким активом, как гараж или парковочное место в крытом гараже, которая не представлена в материалах РМЭЗ: за наблюдаемый период доля владельцев гаражей несколько уменьшилась с 15\% в 2011 г. до 13\% в 2018 г. Хотя в анкете КОУЖ и не уточняется, оформлено ли право собственности на гараж, тем не менее эти данные представляют собой многоаспектный интерес, в т. ч. в плане соотнесения с масштабом владельцев автомобилей: автомобили у домохозяйств встречаются более чем в три раза чаще, чем гаражи для них. Да и увеличение собственников автомобилей не сопровождается увеличением собственников гаражей, более того, расчеты показывают, что более $10 \%$ владельцев гаражей не имеют автомобиля, т. е. гараж может рассматриваться не только как связанный с владением автомобилем элемент богатства, но и самостоятельный актив, который можно при необходимости продать или сдать в аренду.

И государственная статистика, и данные социально-экономических обследований населения демонстрируют, что за новейшую 30-летнюю историю России отечественные домохозяйства заметным образом нарастили свой имущественный ресурс, подавляющее большинство домохозяйств и их членов стали выступать в роли собственника как минимум одного из элементов нефинансового богатства с сопутствующей этой роли обязанностью платить налоги на собственность. 


\section{Государственное регулирование прав собственности и налогообложение имущества населения в России}

Система налогообложения собственности населения в любой стране выстраивается с учетом имущественной обеспеченности граждан. Поскольку администрирование налогов является достаточно дорогостоящей процедурой, принципиальное значение для введения того или иного актива в перечень налогооблагаемых объектов имеет величина доли населения, обладающего этим активом. Изменение налоговых ставок на тот или иной актив и/или активы определенного качества (повышенной стоимости, того или иного срока эксплуатации и т. п.) как основы исчисления налогов привязано к оценке структуры собственности с учетом качества активов, доли среди владельцев обладателей объектов премиум-класса, как и доли такой премиальной собственности среди всех активов. Целью для такого рода фискальных процедур может служить как увеличение сборов, пополняющих государственную казну, стимулирование более эффективного использования активов домохозяйствами, так и реализация принципа справедливости, когда большую налоговую нагрузку несут владельцы дорогостоящих активов.

В последние десятилетия российское государство было активно в поле налоговых инициатив, связанных с собственностью населения. Оно методично отстраивало систему регулирования прав собственности и налогообложения имущества граждан - шаг за шагом.

"Персонализация" прав собственности на землю и «дачная амнистия». Федеральный закон № 101 от 24 июля 2002 г. «Об обороте земель сельскохозяйственного назначения» был призван превратить виртуальные права собственности на землю во владение конкретными участками и разрешал свободную куплю-продажу земли, но процесс юридической регистрации был связан с высокими материальными и временными издержками из-за сложных бюрократических процедур и высоких цен на освидетельствование и межевание земельных участков. Процедура легализации земельной собственности была отчасти упрощена с принятием в 2006 г. Федерального закона № 93-Ф3 «О внесении изменений в некоторые законодательные акты Российской Федерации по вопросу оформления в упрощенном порядке прав граждан на отдельные объекты недвижимого имущества» и в 2010 г. Федерального закона № 435-Ф3 «О внесении изменений в отдельные законодательные акты Российской Федерации в части совершенствования оборота земель сельскохозяйственного назначения», получивших неформальное обозначение «дачная амнистия». Стало возможным в упрощенном порядке оформить права граждан на земельные участки, предоставленные им до введения в действие Земельного кодекса РФ (до 30.10.2001), для ведения личного подсобного хозяйства, дачного хозяйства, огородничества, садоводства, индивидуального жилищного или гаражного строительства; обязательное условие такого оформления прав собственности состояло в получении кадастрового плана или кадастрового паспорта (с 2008 г.) на участок с описанием его месторасположения и границ.

Систематический рост транспортного налога начиная с 2010-х г2. в привязке к мощности двигателя, стоимости и года выпуская автомобилей и друzих трансnортных средств. Транспортный налог является региональным налогом, устанавливается законами субъектов Российской Федерации о налоге. Налогоплательщиками транспортного налога становятся лица, на которых в соответствии с за- 
конодательством Российской Федерации зарегистрированы транспортные средства, являющиеся объектом налогообложения. Объектом налогообложения признаются автомобили, мотоциклы, мотороллеры, автобусы и другие самоходные машины и механизмы на пневматическом и гусеничном ходу, самолеты, вертолеты, теплоходы, яхты, парусные суда, катера, снегоходы, мотосани, моторные лодки, гидроциклы, несамоходные (буксируемые суда) и другие водные и воздушные транспортные средства (далее в настоящей главе - транспортные средства), зарегистрированные в установленном порядке в соответствии с законодательством Российской Федерации'.

С 2010 г. Федеральным законом от 28.11.2009 № 282-Ф3 «О внесении изменений в главы 22 и 28 части второй Налогового кодекса Российской Федерации» расширены полномочия субъектов Федерации по сбору транспортного налога: им предоставлено право увеличить или уменьшить установленную в Налоговом кодексе ставку налога, но не более чем в десять раз (до 2010 г. - не более чем в пять pa $\left.{ }^{10}\right)$. Предложение одной из парламентских партий в 2012 г. по снижению налогообложения для транспортных средств, используемых сезонно (например, мотоцикл, снегоход), не получило поддержки и не было закреплено законодательно.

Повышающие коэффициенты на транспортный налог для владельцев дорогих автомобилей или так называемый налог на роскошь начал действовать с 2014 г. Владельцы автомобилей стоимостью от 3 млн до 5 млн руб. должны платить транспортный налог с коэффициентом 1,1, пока с момента выпуска машины прошло не более трех лет. Владельцы машин дороже 5 млн руб. и не старше пяти лет платят налог в двойном размере, а на автомобили дороже 10 млн руб. и возрастом до десяти лет - в тройном. Министерство промышленности и торговли РФ ежегодно формирует перечень автомобилей со средней стоимостью более 3 млн руб. и публикует его на своем сайте, из года в год расширяя список: в 2014 г. в этом списке были зафиксированы 187 марок автомобилей и их моделей [Зыкова 2015], а в 2021 г. - 1387 [Перечень легковых автомобилей 2021].

Переход от инвентаризационной к кадастровой стоимости недвижимости при налогообложении. С 2015 г. в Налоговый кодекс введена новая глава 32 «Налог на имущество физических лиц», регламентирующая состав объектов налогообложения (жилой дом; квартира, комната; гараж, машино-место; единый недвижимый комплекс; объект незавершенного строительства; иные объекты (здание, строение, сооружение, помещение)), а также налоговую базу, ставки и льготы [Налоговый кодекс]. С 2015 г. в ряде экспериментальных регионов налог на имущество начал рассчитываться по кадастровой, более приближенной к рыночной, а не инвентаризационной стоимости объекта, что привело к увеличению суммы налога. Постепенно в каждом субъекте Федерации должны были принять нормативные акты об определении налоговой базы по налогу на имущество физических лиц исходя из кадастровой стоимости. С 1 января 2020 г. кадастровая стоимость объектов недвижимости стала основой для исчисления налогов повсеместно в стране.

Признание парковочных мест в зданиях недвижимым имуществом. Согласно Федеральному закону от 03.07.2016 № 315-Ф3 «О внесении изменений

\footnotetext{
9 Транспортный налог. Физическим лицам и предпринимателям // https://www.nalog.ru/rn77/taxation/taxes/tr_ul/ transport_fl/, дата обращения 24.03.2021

10 Изменен порядок установления ставок транспортного налога // http://www.consultant.ru/document/cons_doc_ LAW_95389/541cb48d711e0c4bcf4effd7fd19a559429638ab/, дата обращения 21.04.2021.
} 


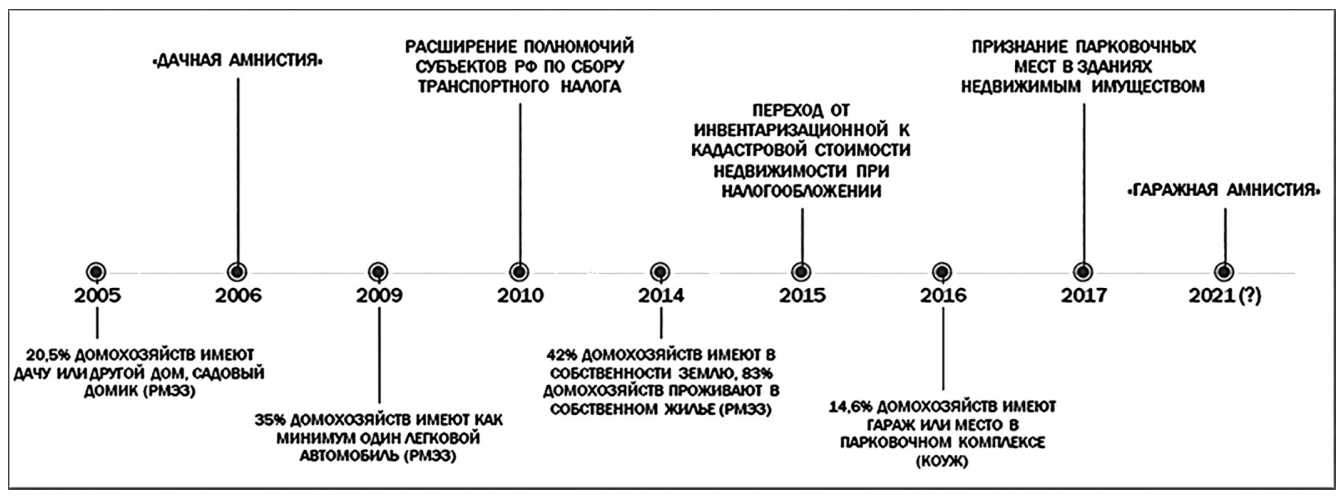

Рисунок 2. Хронология налоговых новаций государства в привязке к уровню обеспеченности российских домохозяйств активами, связанными с соответствуюшими налоговыми мерами (наше время)

Таблица 4. Доля имущественных налогов населения в совокупных налоговых поступлениях в консолидированный бюджет РФ и консолидированные бюджеты субъектов РФ, 2011-2020 гг., \%

\begin{tabular}{|l|c|c|c|c|c|c|}
\hline & $\mathbf{2 0 1 1}$ & $\mathbf{2 0 1 3}$ & $\mathbf{2 0 1 5}$ & $\mathbf{2 0 1 7}$ & $\mathbf{2 0 1 9}$ & $\mathbf{2 0 2 0}$ \\
\hline $\begin{array}{l}\text { Всего поступило в консолидированный } \\
\text { бюджет РФ, млрд руб. }\end{array}$ & $\mathbf{9 7 2 0 , 0}$ & $\mathbf{1 1 3 2 7 , 2}$ & $\mathbf{1 3 7 8 8 , 3}$ & $\mathbf{1 7 3 4 3 , 4}$ & $\mathbf{2 2 7 3 7 , 3}$ & $\mathbf{2 1 0 1 4 , 2}$ \\
\hline Налог на имущество физических лиц & 0,05 & 0,19 & 0,22 & 0,3 & 0,31 & 0,37 \\
\hline Транспортный налог с физических лиц & 0,64 & 0,71 & 0,80 & 0,74 & 0,63 & 0,72 \\
\hline $\begin{array}{l}\text { Земельный налог в консолидированные } \\
\text { бюджеты субъектов РФ }\end{array}$ & 1,26 & 1,38 & 1,34 & 1,07 & 0,81 & 0,86 \\
\hline $\begin{array}{l}\text { Всего поступило в консолидированные } \\
\text { бюджеты субъектов РФ, млрд руб. }\end{array}$ & $\mathbf{5 2 3 9 , 1}$ & $\mathbf{5 9 5 9 , 2}$ & $\mathbf{6 9 0 7 , 8}$ & $\mathbf{8 1 8 1 , 5}$ & $\mathbf{1 0 1 2 5 , 5}$ & $\mathbf{1 0 0 3 5 , 4}$ \\
\hline \multicolumn{1}{|c|}{$\%$} & 100,0 & 100,0 & 100,0 & 100,0 & 100,0 & 100,0 \\
\hline Налог на имущество физических лиц & 0,09 & 0,37 & 0,43 & 0,63 & 0,70 & 0,78 \\
\hline Транспортный налог с физических лиц & 1,19 & 1,36 & 2,76 & 1,56 & 1,41 & 1,51 \\
\hline $\begin{array}{l}\text { Земельный налог в консолидированные } \\
\text { бюджеты субъектов РФ }\end{array}$ & 2,33 & 2,63 & 3,04 & 2,27 & 1,82 & 1,80 \\
\hline
\end{tabular}

Источник: рассчитано авторами на основе материалов «Аналитической справки о поступлении администрируемых ФНС России доходов в консолидированный бюджет Российской Федерации», публикуемых ежегодно с 2011 г. на сайте ФНС РФ как данные на 1 января каждого года // https://analytic.nalog.ru/portal/index.ru-RU.htm 
в часть первую Гражданского кодекса Российской Федерации и отдельные законодательные акты Российской Федерации» с 1 января 2017 г. машино-место как один из спорных в юридическом плане объектов правоотношений стал объектом недвижимости: «К недвижимым вещам относятся жилые и нежилые помещения, а также предназначенные для размещения транспортных средств части зданий или сооружений (машино-места), если границы таких помещений, частей зданий или сооружений описаны в установленном законодательством о государственном кадастровом учете порядке» ${ }^{11}$. Это позволяет ставить неизолированные части зданий на кадастровый учет, регистрировать на них права и вовлекать в гражданский оборот (передавать по наследству, продавать и т. п.).

«Гаражная амнистия». В феврале 2020 г. в Правительство РФ был представлен проект Федерального закона «О внесении изменений в отдельные законодательные акты Российской Федерации в целях урегулирования вопросов приобретения гражданами прав на гаражи и земельные участки, на которых они расположены», разработанный Минэкономразвития России совместно с Росреестром. Законопроект определяет, что такое «гараж», и предлагает механизм оформления прав на гаражные строения и земельные участки, находящиеся в государственной или муниципальной собственности, на которых размещены гаражи, построенные до введения в действие Градостроительного кодекса РФ. По оценкам Росреестра, незарегистрированными являются более 3,5 млн гаражей по всей стране, однако «количество фактически существующих, но не оформленных в установленном порядке объектов значительно выше» [Законопроект о «гаражной амнистии» 2020]. Предполагается, что законопроект вступит в силу в 2021 г., его реализация продлится до 2025 г.

Все рассмотренные активности государства в налоговом поле не автономны, а естественным образом вписываются в экономический и институциональный контекст. При принятии государством решений о введении в действие (внесение изменений) или вынесении на обсуждение в Государственную Думу тех или иных налоговых законопроектов, скорее всего, учитывалась доля среди домохозяйств собственников того или иного актива, делалась качественная и стоимостная оценка находящихся в собственности активов. Величина доли домохозяйств, владеющих тем или иным активом, в определенные моменты времени рассматривалась государством как достаточная для того, чтобы повысить налоговое бремя на всех собственников или владельцев активов премиум-класса, включить актив в состав недвижимого имущества, облагаемого налогом, запустить стимулирование населения и введение санкций с целью перехода от владения активами де-факто к владению де-юре и прочее. В пользу этого говорит хронология выхода государства с обозначенными выше налоговыми новациями, соотнесенная с данными об обеспеченности населения соответствующими активами (рисунок 2).

Общее представление о выстроенной в России системе налогообложения собственности граждан могут дать доступные для анализа данные о налоговых поступлениях за 2011-2020 гг. Они показывают, что общий вклад поступлений налогов на собственность населения в бюджет РФ трудно назвать значительным (в сумме немногим больше 1\%) (таблица 4). Не претендуя на чистое сопоставление

\footnotetext{
11 Федеральный закон «О внесении изменений в часть первую Гражданского кодекса Российской Федерации и отдельные законодательные акты Российской Федерации» от 03.07.2016 № 315 -Ф3 // http://www.consultant.ru/document/cons_doc_LAW_200688/, дата обращения 21.04.2021.
} 
российских данных с показателями вклада налогов на собственность в общие налоговые поступления в странах ОЭСР (таблица 2), можно сказать, что в России вклад значительно меньше как в общие поступления в бюджет, так и в консолидированные бюджеты субъектов РФ (рассматриваемые налоги на собственность в нашей стране являются региональными и местными налогами). Но как бы скромно ни смотрелся вклад налогов на собственность в совокупных региональных налогах, поступающие суммы безусловно важны для поддержания и развития инфраструктуры на местах.

Следует отметить, что по видам имущественных налогов наблюдается различная динамика - от устойчивого роста вклада налога на имущество физических лиц (в диапазоне $0,05-0,37 \%$ ) и тенденции увеличения вклада (хотя и не устойчивой) транспортного налога с физических лиц $(0,64-0,72 \%)$ до уменьшения вклада земельного налога $(1,26-0,86 \%)^{12}$. Тем не менее представленные в абсолютном выражении (в млрд руб.) поступления налогов на собственность физических лиц за 2011-2020 г. выросли по всем рассматриваемым активам (рисунок 3).

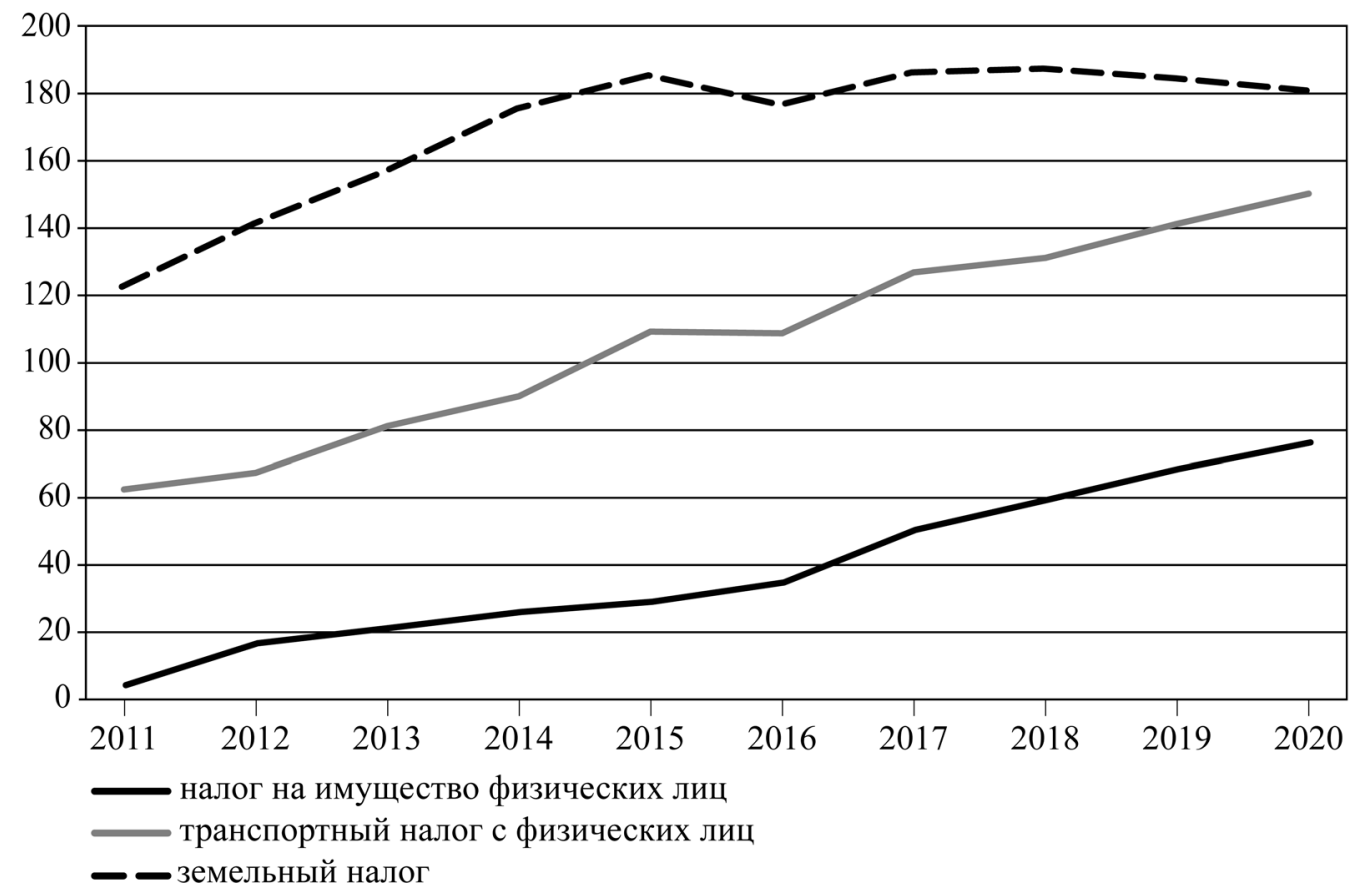

Рисунок 3. Динамика поступлений от налогов на собственность населения в России, 2011-2020 гг., млрд руб.

Источник: материалы «Аналитической справки о поступлении администрируемых ФНС России доходов в консолидированный бюджет Российской Федерации» // https://analytic.nalog.ru/portal/index.ru-RU.htm

\footnotetext{
12 Земельный налог, как и налог на имущество, транспортный налог, разделяется на налог с физических лиц и организаций. В тех налоговых аналитических документах, к которым мы обращаемся, по земельному налогу такое разделение не сделано, что означает, что вклад земельного налога с физических лиц еще меньше также и по всем другим аспектам упоминания в нашей статье этого налога.
} 
Если соотнести годовые темпы роста поступлений с индексом цен на потребительские товары и услуги по доступным данным за 2014-2019 гг., то можно увидеть, что в анализируемый период прирост и поступлений налогов на имущество, и поступлений от транспортного налога физических лиц уверенно обгоняет темпы инфляции ${ }^{13}$ (таблица 5). Но в случае земельного налога, даже когда наблюдается прирост поступлений, он в основном «съедается» инфляцией.

\section{Таблица 5. Годовые темпы роста поступлений имущественных налогов населения} в бюджет РФ и темпы инфляции, 2014-2019 гг., \%

\begin{tabular}{|l|c|c|c|c|c|c|c|}
\hline & $\mathbf{2 0 1 3}$ & $\mathbf{2 0 1 4}$ & $\mathbf{2 0 1 5}$ & $\mathbf{2 0 1 6}$ & $\mathbf{2 0 1 7}$ & $\mathbf{2 0 1 8}$ & $\mathbf{2 0 1 9}$ \\
\hline $\begin{array}{l}\text { Поступления налога на имущество } \\
\text { физических лиц, \% к предыдущему году* }\end{array}$ & & 121,8 & 111,6 & 119,1 & 144,7 & 117,4 & 115,2 \\
\hline $\begin{array}{l}\text { Поступления транспортного налога } \\
\text { с физических лиц, \% к предыдущему году* }\end{array}$ & & 111,0 & 121,6 & 99,4 & 116,9 & 103,5 & 107,8 \\
\hline $\begin{array}{l}\text { Поступления земельного налога, } \\
\text { \% к предыдущему году* }\end{array}$ & & 112,0 & 105,6 & 95,3 & 105,4 & 100,6 & 98,5 \\
\hline Индекс потребительских цен** & 106,47 & 111,35 & 112,91 & 105,39 & 102,51 & 104,26 & \\
\hline
\end{tabular}

Источники:

* Данные об объемах поступления разных видов налогов в бюджет РФ на 1 января каждого года и в процентах к предыдущему году опубликованы в «Аналитической справке о поступлении администрируемых ФНС России доходов в консолидированный бюджет Российской Федерации» // https://analytic.nalog.ru/portal/index.ru-RU.htm ** Данные о динамике индекса потребительских цен. Росстат. «Витрина данных»// https://showdata.gks.ru/report/274270/

На основе этого можно заключить, что к концу 2010-х гг. выстроенная в РФ система налогообложения имущества и транспортных средств физических лиц обладала достаточным объемом объектов и субъектов налогообложения и грамотно выстроенным администрированием данных налогов, чтобы иметь, как минимум, прирост реальных, а не номинальных поступлений. Тот факт, что рост абсолютных объемов поступлений от налогов на имущество и транспортные средства физических лиц (рисунок 3) в 2011-2018 гг. происходил на фоне стабильности доли обладателей этих активов (рисунок 1), свидетельствует о том, что прирост налоговых поступлений был обеспечен прежде всего за счет налоговых новаций, связанных с учетом рыночной стоимости активов.

\footnotetext{
13 В таблице 4 данные темпов роста налоговых поступлений надо сопоставлять с индексом потребительских цен со смещением ячеек справа налево: показатель «темп роста поступлений» рассчитывается как соотношение между величиной собранных налогов на 1 января указанного года и величиной собранных налогов на 1 января предшествующего года, а индекс потребительских цен рассчитывается за предшествующий указанному год. Например, с 1 января 2013 г. по 1 января 2014 г. темп роста поступлений налога на имущество физических лиц составил 121,8\%, а индекс потребительских цен за 2013 г. - 106,47\%.

14 Таблица 5 сформирована авторами на основе обращения к данным Росстата и Федеральной налоговой службы России.
} 


\section{Заключение}

В российской экономической социологии тема изучения собственности населения и разных аспектов экономического поведения, связанного с управлением и использованием собственности, находится на начальной стадии проработки. Векторов исследования можно наметить множество.

В данной статье мы попытались наметить контуры механизма, где между собой увязаны действия государства по созданию институциональных условий для укрепления российских домохозяйств в качестве собственников и его фискальная политика. Казалось бы, очевидно, что каким бы путем ни вырос и окреп собственник - вопреки или благодаря содействию государства, - государство будет снимать с него подать в виде налогов. Но грамотная политика государства заключается в том, чтобы выбрать такой момент времени, объект, способ налогообложения, которые бы «не убили, а сделали сильнее» собственника, не демотивировали к накоплению, а стимулировали выбор в приобретении релевантных его экономическим компетенциям активов и подтолкнули к поиску эффективных способов использования имеющихся и новых объектов собственности. С увеличением нефинансового богатства домохозяйства станут все более самостоятельным рыночном актором, который хоть и обязан в силу статуса собственника платить налоги суверену, может рано или поздно потребовать отчета у государства и по качеству налогового администрирования, и по эффективности расходования налоговых поступлений. Наращивание и диверсификация собственности российских домохозяйств будут сопровождаться ростом финансовой грамотности населения и освоением разнообразных практик оперирования активами, выстраивания домохозяйствами собственной политики в ответ на стимулы государства и фискальные виражи. Как это ни парадоксально, но нет гарантии роста налоговых поступлений от собственности даже при поступательном росте имущественной обеспеченности. Как показывает опыт стран Организации экономического сотрудничества и развития, «несмотря на рост благосостояния в последние десятилетия, доля доходов от налога на имущество в средней структуре налогов по ОЭСР со временем снизилась» [OECD 2018, p. 24]. Рост богатства во всех частях спектра российских домохозяйств (а не только верхнего сегмента стратификации по нефинансовому богатству), выстраивание государством налоговой политики с учетом не только объема и состава портфеля активов у собственников, но их интересов в долгосрочной перспективе - это основа поступательного развития общества.

Важное значение в развертывании этих тезисов имеют оценка концентрации налогооблагаемых активов среди российских домохозяйств, определение типичных сочетаний налогооблагаемых активов, оценка потенциальных поведенческих реакций собственников на стимулы по приращению активов и инициативы государства по регулированию прав собственности, в т. ч. с помощью налогообложения, которые могут стать перспективными направлениями исследований собственности в России.

\section{Литература}

Богомолова Т.Ю., Черкашина Т.Ю. (2018) текст формирования нефинансового

Институционально-экономический конбогатства российских домохозяйств: 
от приватизации к приобретению // Мир России. Т. 27. № 2. С. 62-89. DOI: 10.17323/1811-038X-2018-27-2-62-89

Богомолова Т.Ю., Черкашина Т.Ю. (2020) Стратификация по нефинансовому богатству российских домохозяйств: высота, профиль, детерминанты // Мир России. Т. 29. № 4. C. 6-33. DOI: 10.17323/1811-038X-2020-29-4-6-33

Годовой отчет (2014) // Пенсионный фонд РФ // http://www.pfrf.ru/files/id/press_center/godovoi_otchet/godovoi_otchet_2014_1.pdf, дата обращения 28.04.2021.

Годовой отчет (2017) // Пенсионный фонд РФ // http://www.pfrf.ru/files/id/press_center/godovoi_otchet/annual_report_2017_1.pdf, дата обращения 28.04.2021.

Годовой отчет (2018) // Пенсионный фонд РФ // http://www.pfrf.ru/files/id/press_center/ godovoi_otchet/Pension-fund-Annual-report-2018.pdf, дата обращения 28.04.2021.

Государственный (национальный) доклад о состоянии и использовании земель в Российской Федерации (2018) // Федеральная служба государственной регистрации, кадастра и картографии (Росреестр). 2018 // https://rosreestr.gov.ru/site/activity/gosudarstvennyy-natsionalnyydoklad-o-sostoyanii-i-ispolzovanii-zemel-rossiyskoy-federatsii/, дата обращения 28.04.2021.

Законопроект о «гаражной амнистии» внесен в Правительство (2020) // Министерство экономического развития Российской Федерации. 13 февраля 2020 // https://www.economy.gov.ru/material/news/zakonoproekt_o_garazhnoy_amnistii_ vnesen v pravitelstvo.html, дата обращение 11.07.2020.

Зыкова Т. (2015) Въехали в налог. Минпромторг признал роскошью 279 марок автомобилей // Российская газета. 9 апреля 2015 // https://rg.ru/2015/04/09/avto-site-anons.html, дата обращения 28.04.2021.

Налоговый кодекс Российской Федерации // Федеральная налоговая служба // http://nalog.garant.ru/fns/nk, дата обращения 17.01. 2021.

О продлении программы льготного автокредитования (2018) // Правительство РФ. 30 июля 2018 // http://government.ru/docs/33417/, дата обращения 28.04.2021.

Перечень легковых автомобилей средней стоимостью от 3 миллионов рублей, подлежащий применению в очередном налоговом периоде (2021) // Минпромторг РФ. 26 февраля 2021 // https://minpromtorg.gov.ru/docs/\#!perechen_legkovyh_avtomobiley_sredney_ stoimostyu_ot 3 millionov_rubley_podlezhashhiy_primeneniyu_v_ocherednom nalogovom_periode_2021_god, дата обращения 28.04.2021.

Постановление Правительства Российской Федерации от 7 декабря 2019 г. № 1609 «Об утверждении условий программы “Дальневосточная ипотека" и внесении изменений в распоряжение Правительства Российской Федерации от 2 сентября 2015 г. № 1713-р» (2019) // Правительство РФ. 9 декабря 2019 // http://government.ru/docs/38551, дата обращения 28.04.2021.

Постановление Правительства РФ от 23 апреля 2020 г. № 566 «Об утверждении Правил возмещения кредитным и иным организациям недополученных доходов по жилищным (ипотечным) кредитам (займам), выданным гражданам Российской Федерации в 2020 и 2021 годах» (2020) // Правительство РФ. 23 апреля 2020 // http://government.ru/docs/39558/, дата обращения 28.04.2021.

Регионы России. Социально-экономические показатели (2019). Стат. сб. М.: Росстат // https://rosstat.gov.ru/folder/210/document/13204, дата обращения 28.04.2021.

Российский статистический ежегодник (2019). Стат. сб. М.: Росстат // https://rosstat.gov.ru/folder/210/document/12994, дата обращения 28.04.2021.

Сакаева M.M. (2016) Права собственности в фокусе социологических теорий: через размывание границ к междисциплинарности // Экономическая социология. Т. 17. № 3. С. 110-131.

Транспорт в России (2020) // Федеральная служба государственной статистики РФ. 30 ноября 2020 // https://rosstat.gov.ru/folder/210/document/13229, дата обращение 08.02.2021.

Транспорт и связь в России (2018) // Федеральная служба государственной статистики РФ. 5 сентября 2018 // https://rosstat.gov.ru/folder/210/document/13228, дата обращение 08.02.2021.

Федеральный закон от 03.07.2019 № 157-Ф3 «О мерах государственной поддержки семей, имеющих детей, в части погашения обязательств по ипотечным жилищным кредитам 
(займам) и о внесении изменений в статью 13-2 Федерального закона “Об актах гражданского состояния”» (2019) // Официальный интернет-портал правовой информации. 3 июля 2019 // http://publication.pravo.gov.ru/Document/View/0001201907030027, дата обращения 28.04.2021.

Bricker J., Henriques A., Krimmer J., Sabelhaus J. (2016) Measuring Income and Wealth at the Top Using Administrative and Survey Data // Brookings Papers on Economic Activity, Spring, pp. 261-312 // https://www.jstor.org/stable/43869025, дата обращения 28.04.2021.

Carruthers G., Ariovich L. (2004) The Sociology of Property Rights // Annual Review of Sociology, vol. 30, pp. 23-46.

Jianakopolos N.A., Menchik P.L. (1997) Wealth Mobility // The Review of Economics and Statistics, vol. 79, no 1, pp. 18-31.

Keister L., Moller S. (2000) Wealth Inequality in the United States // Annual Review of Sociology, vol. 26 , pp. $63-81$.

Nau M., Tumin D. (2012) Wealth Transfer Receipt and Later Life Wealth // Research in Social Stratification and Mobility, vol. 30, no 3, pp. 233-245.

OECD (2013). Framework for Statistics on the Distribution of Household Income, Consumption and Wealth. DOI: 10.1787/9789264194830-en

OECD (2015). In It Together: Why Less Inequality Benefits All // http://s3.documentcloud.org/documents/2084674/in-it-together.pdf, дата обращения 28.04.2021.

OECD (2018). The Role and Design of Net Wealth Taxes in the OECD, OECD Tax Policy Studies, No. 26, OECD Publishing, Paris. DOI: 10.1787/9789264290303-en

OECD (2021). Tax Levels and Tax Structures, 1965-2019 / Revenue Statistics 2020. OECD Publishing, Paris, pp. 55-76. DOI: 10.1787/c06c9de9-en

Paiella M. (2007) Does Wealth Affect Consumption? Evidence for Italy // Journal of Macroeconomics, vol. 29, no 1, pp. 189-205.

Wolff E.N. (1990) Methodological Issues in the Estimation of the Size Distribution of Household Wealth // Journal of Econometrics, vol. 43, no 1-2, pp. 179-195.

Zucman G. (2016) Wealth Inequality // State of the Union: The Poverty and Inequality Report. Pathways. Special Issue 2016. No. 26, Stanford Center on Poverty and Inequality, pp. 39-44 // https://inequality.stanford.edu/sites/default/files/Pathways-SOTU-2016.pdf, дата обращения 28.04.2021.

\title{
The Non-financial Wealth of Russian Households: Property and Taxes
}

\author{
T. BOGOMOLOVA*, T. CHERKASHINA**
}

*Tatyana Bogomolova - PhD in Sociology, Head of Department of Social Problems, Institute of Economics and Industrial Engineering, Siberian Branch of the Russian Academy of Sciences; Dean of the Faculty of Economics, Novosibirsk State University. Address: 17 Academic Lavrentiev Ave., Novosibirsk, 630090, Russian Federation. E-mail: bogtan@rambler.ru

**Tatyana Cherkashina - PhD in Sociology, Leading Researcher, Institute of Economics and Industrial Engineering, Siberian Branch of the Russian Academy of Sciences; Head of Department of General Sociology, Novosibirsk State University. Address: 17 Academic Lavrentiev Ave., Novosibirsk, 630090, Russian Federation. E-mail: touch@nsu.ru 
Citation: Bogomolova T., Cherkashina T. (2021) The Non-financial Wealth of Russian Households: Property and Taxes. Mir Rossii, vol. 30, no 3, pp. 51-77 (in Russian). DOI: $10.17323 / 1811-038 X-2021-30-3-51-77$

\begin{abstract}
Owning property comes with financial obligations: property acquisition leveraged by debt entails the need to pay off the debt; property taxation entails the need to pay taxes. This article reviews (1) trends in the accumulation of property (non-financial wealth) by Russian households since the mid-1990s and (2) the state's efforts to increase the transparency of the rights and obligations associated with private property ownership (e.g., the introduction of a cadastral registration system, the taxation of property according to its cadastral value) and the stimulation of property acquisition through various government programs. The study analyses state legislation, administrative documents, departmental statistics, analytical reports and survey data (the Russian Longitudinal Monitoring Survey of the Higher School of Economics 1994-2018 and the General Monitoring of Living Conditions by Rosstat in 2011, 2014, 2016, 2018). Since the mid-1990s the ownership of consumer property (housing, cars, summer houses), investment property and additional housing increased, while the ownership of productive property (land) decreased. Our analysis indicates that the state's effort to increase the transparency of property ownership and to improve the collection of relevant taxes has not disincentivized Russians from owning property.
\end{abstract}

Keywords: household wealth, non-financial wealth, property, sociology of property rights, taxation, state

\title{
References
}

Bricker J., Henriques A., Krimmer J., Sabelhaus J. (2016) Measuring Income and Wealth at the Top Using Administrative and Survey Data. Brookings Papers on Economic Activity, Spring, pp. 261-312. Available at: https://www.jstor.org/stable/43869025, accessed 28.04.2021.

Bogomolova T., Cherkashina T. (2018) Institutsional'no-ekonomicheskij kontekst formirovaniya nefinansovogo bogatstva rossijskikh domohozyajstv: ot privatizatsii $\mathrm{k}$ priobreteniyu [The Institutional and the Economic Context of the Formation of Non-financial Wealth in Russian Households: From Privatization to Acquisition]. Mir Rossii, vol. 27, no 2, pp. 62-89. DOI: 10.17323/1811-038X-2018-27-2-62-89

Bogomolova T., Cherkashina T. (2020) Stratifikaciya po nefinansovomu bogatstvu rossijskih domohozyajstv: vysota, profil', determinanty [Stratification of Russian Households by Non-financial Wealth: Volume, Structure and Correlates]. Mir Rossii, vol. 29, no 4, pp. 6-33. DOI: 10.17323/1811-038X-2020-29-4-6-33

Carruthers G., Ariovich L. (2004) The Sociology of Property Rights. Annual Review of Sociology, vol. 30, pp. 23-46.

Federal'nyj zakon ot 03.07.2019 № 157-FZ «O merah gosudarstvennoj podderzhki semej, imeyushchih detej, v chasti pogasheniya obyazatel'stv po ipotechnym zhilishchnym kreditam (zajmam) i o vnesenii izmenenij v stat'yu 13-2 Federal'nogo zakona “Ob aktah 
grazhdanskogo sostoyaniya"» [Federal Law No. 157-FZ of 03.07.2019 “On Measures of State Support for Families with Children in Terms of Repayment of Obligations under Mortgage Housing Loans (Loans) and on Amendments to the Article 13-2 of the Federal Law "On Acts of Civil Status"'”] (2019). Official Internet Portal of Legal Information, July 3, 2019. Available at: http://publication.pravo.gov.ru/Document/View/0001201907030027, accessed 28.04.2021.

Godovoj otchet [Annual Report] (2014). Pension Fund of the Russian Federation. Available at: http://www.pfrf.ru/files/id/press_center/godovoi_otchet/godovoi_otchet_2014_1.pdf, accessed 28.04.2021.

Godovoj otchet [Annual Report] (2017). Pension Fund of the Russian Federation. Available at: http://www.pfrf.ru/files/id/press_center/godovoi_otchet/annual_report_2017_1.pdf, accessed 28.04.2021.

Godovoj otchet [Annual Report] (2018). Pension Fund of the Russian Federation. Available at: http://www.pfrf.ru/files/id/press_center/godovoi_otchet/Pension-fund-Annualreport-2018.pdf, accessed 28.04.2021.

Gosudarstvennyj (natsional'nyj) doklad o sostoyanii i ispol'zovanii zemel'v Rossijskoj Federatsii [The State (National) Report on the Status and Use of Land in Russian Federation] (2018). The Federal Service for State Registration, Cadastre and Cartography. Available at: https://rosreestr.gov.ru/site/activity/gosudarstvennyy-natsionalnyy-doklad-o-sostoyanii-iispolzovanii-zemel-rossiyskoy-federatsii, accessed 28.04.2021.

Jianakopolos N.A., Menchik P.L. (1997) Wealth Mobility. The Review of Economics and Statistics, vol. 79, no 1, pp. 18-31.

Keister L., Moller S. (2000) Wealth Inequality in the United States. Annual Review of Sociology, vol. 26, pp. 63-81.

Nalogovyi kodeks Rossiyskoy Federatcii Federalnaya nalogovaya sluzba [Tax Code of the Russian Federation]. Federal Tax Service. Available at: http://nalog.garant.ru/fns/nk, accessed 17.01.2021.

Nau M., Tumin D. (2012) Wealth Transfer Receipt and Later Life Wealth. Research in Social Stratification and Mobility, vol. 30, no 3, pp. 233-245.

O prodlenii programmy l'gotnogo avtokreditovaniya [On the Extension of the Preferential Car Loan Program] (2018). Government of the Russian Federation, July 30, 2018. Available at: http://government.ru/docs/33417, accessed 28.04.2021.

OECD (2013). Framework for Statistics on the Distribution of Household Income, Consumption and Wealth. DOI: 10.1787/9789264194830-en

OECD (2015). In It Together: Why Less Inequality Benefits All. Available at: http://s3.documentcloud.org/documents/2084674/in-it-together.pdf, accessed 28.04.2021.

OECD (2018). The Role and Design of Net Wealth Taxes in the OECD, OECD Tax Policy Studies, No. 26, OECD Publishing, Paris. DOI: 10.1787/9789264290303-en

OECD (2021). Tax Levels and Tax Structures, 1965-2019/ Revenue Statistics 2020. OECD Publishing, Paris, pp. 55-76. DOI: 10.1787/c06c9de9-en

Paiella M. (2007) Does Wealth Affect Consumption? Evidence for Italy. Journal of Macroeconomics, vol. 29, no 1, pp. 189-205.

Perechen' legkovyh avtomobilej srednej stoimost'yu ot 3 millionov rublej, podlezhashchij primeneniyu $\mathrm{v}$ ocherednom nalogovom periode [The List of Passenger Cars with an Average Value of 3 Million Rubles or More to Be Applied in the Next Tax Period] (2021). The Ministry of Industry and Trade of the Russian Federation, February 26, 2021. Available at: https://minpromtorg.gov.ru/docs/\#!perechen_legkovyh_avtomobiley_ sredney_stoimostyu_ot_3_millionov_rubley_podlezhashhiy_primeneniyu_v_ ocherednom nalogovom periode 2021 gōd, accessed 28.04.2021.

Postanovlenie ot 7 dekabrya $2019^{-}$g. № 1609 «Ob utverzhdenii uslovij programmy "Dal'nevostochnaya ipoteka" i vnesenii izmenenij v rasporyazhenie Pravitel'stva Rossijskoj Federacii ot 2 sentyabrya 2015 g. № 1713-r» [Resolution No. 1609 of December 7, 2019 "On Approval of the Terms of the Far Eastern Mortgage Program and Amendments to Order No. 1713-r of the Government of the Russian Federation of September 2, 2015"] (2019). Government of the Russian Federation, December 9, 2019. Available at: http://government.ru/docs/38551, accessed 28.04.2021. 
Postanovlenie Pravitel'stva RF ot 23 aprelya 2020 g. № 566 «Ob utverzhdenii Pravil vozmeshcheniya kreditnym i inym organizaciyam nedopoluchennyh dohodov po zhilishchnym (ipotechnym) kreditam (zajmam), vydannym grazhdanam Rossijskoj Federacii v 2020 i 2021 godah» [Resolution of the Government of the Russian Federation of April 23, 2020 No. 566 "On Approval of the Rules for Compensation to Credit and Other Organizations of Lost Income on Housing (Mortgage) Loans (Loans) Issued to Citizens of the Russian Federation in 2020 and 2021"] (2020). Government of the Russian Federation, April 23, 2020. Available at: http://government.ru/docs/39558, accessed 28.04.2021.

Regiony Rossii. Social'no-ekonomicheskie pokazateli [Regions of Russia. Socio-economic Indicators] (2019), Moscow: Rosstat. Available at: https://rosstat.gov.ru/folder/210/document/13204, accessed 28.04.2021.

Rossijskij statisticheskij ezhegodnik-2019 [Russian Statistical Yearbook] (2019), Moscow: Rosstat. Available at: https://rosstat.gov.ru/folder/210/document/12994, accessed 28.04.2021.

Sakaeva M. (2016) Prava sobstvennosti v fokuse sotsiologicheskikh teoriy: cherez razmyvanie granits k mezhdistsiplinarnosti [Property Rights in the Focus of Social Theories: Through Breaking Boundaries towards the Interdisciplinary]. Journal of Economic Sociology Ekonomicheskaya Sotsiologiya, vol. 17, no 3, pp. 110-131.

Transport i svyaz' v Rossii [Transport and Communications in Russia. Database] (2018). Federal State Statistics Service of the Russian Federation, September 5, 2018. Available at: https://rosstat.gov.ru/folder/210/document/13228, accessed 28.04.2021.

Transport v Rossii [Transport in Russia. Database] (2020). Federal State Statistics Service of the Russian Federation, November 30, 2020. Available at: https://rosstat.gov.ru/folder/210/document/13229, accessed 28.04.2021.

Wolff E.N. (1990) Methodological Issues in the Estimation of the Size Distribution of Household Wealth. Journal of Econometrics, vol. 43, no 1-2, pp. 179-195.

Zakonoproekt o «garazhnoj amnistii» vnesen v Pravitel'stvo [The Bill on "Garage Amnesty" Has Been Submitted to the Government] (2020). Ministry of Economic Development of the Russian Federation, February 13, 2020. Available at: https://www.economy.gov.ru/material/news/zakonoproekt_o_garazhnoy_amnistii_ vnesen $\mathrm{v}$ pravitelstvo.html, accessed 28.04.2021.

Zucman G. (2016) Wealth Inequality. State of the Union: The Poverty and Inequality Report. Pathways. Special Issue 2016. No. 26, Stanford Center on Poverty and Inequality, pp. 39-44. Available at: https://inequality.stanford.edu/sites/default/files/Pathways-SOTU-2016.pdf, accessed 28.04.2021.

Zykova T. (2015) V'ekhali v nalog. Minpromtorg priznal roskosh'yu 279 marok avtomobilej [Bumped into the Tax. 279 Car Brands Recognized as Luxury by the Ministry of Industry and Trade]. Rossijskaya gazeta, April 9, 2015. Available at: https://rg.ru/2015/04/09/avto-site-anons.html, accessed 28.04.2021. 